\title{
PENGARUH KUALITAS SISTEM, KUALITAS INFORMASI, KUALITAS LAYANAN, TERHADAP KEPUASAN PENGGUNA SISTEM INFORMASI AKADEMIK UNIVERSITAS MERDEKA MALANG
}

\author{
Listanto Tri Utomo ${ }^{1}$ Yusaq Tomo Ardianto ${ }^{2}$ Nanik Sisharini ${ }^{3}$ \\ 1.Mahasiswa Magister Manajemen Sistem Informasi, Universitas Merdeka Malang. \\ Email : listanto.utomo@unmer.ac.id \\ 2.Dosen Fakultas Ekonomi dan Bisnis, Universitas Merdeka Malang. \\ Email : yusaqtomo71@gmail.com \\ 3.Dosen Fakultas Ekonomi dan Bisnis, Universitas Merdeka Malang. \\ Email : nik_unmermlg@yahoo.co.id
}

\begin{abstract}
The aims of this article are making explanation on any variables introduced by DeLone and McLean (2003), such as system quality, information quality, service quality, individual impact organization impact, and net benefit. These variables were implemented to the academic information system (SIAKAD) in Universitas Merdeka Malang. By quantitative research, the impact of these variables to the users satisfication will be known. And also, what variable be a most affecting in this system.
\end{abstract}

Keywords: academic information system, DeLone and McLean' variables, organization impact, net benfit.

\section{PENDAHULUAN}

Penggunaan sistem informasi dalam kegiatan usaha dan organisasi sangat dibutuhkan guna meningkatkan efisiensi, produktivitas, daya saing perusahaan di era globalisasi. Hal itu juga berlaku untuk dunia pendidikan dewasa ini. Strategi akademik yang berorientasi pasar sangat diperlukan agar sebuah institusi pendidikan bisa berhasil dalam persaingan di dunia pendidikan. Dengan begitu, seluruh keinginan serta kebutuhan mahasiswa peserta pendidikan bisa terpenuhi (Cravens, 2006). Salah satu faktor penting dalam strategi itu adalah pengembangan sistem informasi.

Teknologi informasi belum mampu untuk meningkatkan kinerja organisasi,di definisikan oleh Ardianto, Y.T et al.,(2013). Berbanding terbalik dengan (Utami et al.,2013) Sistem informasi dapat meningkatkan efektifitas dunia akademik dengan cara mengintegrasikan proses bisnis ke dalam struktur organisasi sekolah. Adapun sistem informasi yang dimaksud dalam hal ini, sebagaimana pernah didefinisikan oleh Davis (1989), adalah "suatu sistem yang menerima input data dan instruksi, mengolah data sesuai dengan instruksi, dan mengeluarkan hasilnya". Sistem informasi juga adalah suatu sistem buatan manusia yang berisi serangkaian terpadu komponen - komponen dan manual bagian - komponen terkomputerisasi yang bertujuan mengumpulkan data, mengolah data, dan menghasilkan informasi bagi pengguna (Sidharta, 1995).

Untuk standar kesuksesan suatu sistem, DeLone dan McLean (1992) memberi enam variabel, yakni (1) kualitas sistem, (2) kualitas informasi, (3) penggunaan, (4) kepuasan pengguna, (5) dampak individu, (6) dan dampak organisasi. Mereka juga menjelaskan bahwa kualitas sistem ditentukan oleh performa perangkat keras, perangkat lunak, kebijakan, serta prosedur sistem informasi, dalam menyediakan informasi kebutuhan pengguna. Kesuksesan sistem informasi juga akan dinilai berdasarkan tingkat kegunaan informasi dalam pembuatan kebijakan-kebijakan organisasi.

Pengembangan model awal dilakukan DeLone dan McLean pada 1992. Akan tetapi, tahun 2003 mereka memperbaharui model awal itu dengan tambahan variabel service quality, serta mengubah variabel individual impact dan organizational impact menjadi net benefit (DeLone \& McLean, 2003). Sevice Quality atau kualitas layanan terkait dengan pelayanan yang diberikan oleh pengembang sistem informasi, dan kepuasan pengguna (User Satisfaction) ditentukan oleh respon pengguna terhadap keluaran (output) sistem informasi (DeLone \& 
McLean, 2003). Kualitas informasi, sistem, dan pelayanan, berpengaruh kepada kepuasan pengguna. Selanjutnya, semua itu juga akan memberi pengaruh kepada manfaat jaringan (net benefit). Model kesuksesan sistem informasi yang dikembangan DeLone dan McLean sangat efektif bila diterapkan dalam berbagai penelitian sistem informasi, termasuk sistem informasi di dunia pendidikan.

Sistem informasi dalam dunia pendidikan lebih dikenal dengan Sistem Informasi Akademik (SIAKAD). Sistem informasi ini memberi layanan informasi berupa data-data terkait kebutuhan akademik. Jenis pelayanannya antara lain: penyimpanan data mahasiswa baru, penentuan jadwal kuliah, pembuatan jadwal mengajar, kartu hasil studi, serta rincian biaya perkuliahan. SIAKAD di Universitas Merdeka Malang dibangun guna memberi kemudahan kepada dosen dan mahasiswa dalam keperluan administrasi akademik di universitas. Sistem ini sangat bermanfaat bagi universitas karena semua data terintegrasi. Data akan selalu diperbaharui dan siap digunakan. Sistem ini juga akan mengurangi kemungkinan duplikasi data karena basis data telah terpusat.

Tulisan ini akan membahas (1) variabel kualitas sistem, kualitas informasi, kualitas layanan SIAKAD di lingkungan Universitas Merdeka Malang. Pembahasan juga akan melihat (2) pengaruh variabel-variabel itu terhadap kepuasan penggunanya, serta (3) variabel mana yang paling berpengaruh. Penelitian ini diharapkan bisa memberi informasi kepada pihak Pusat Komunikasi Universitas Merdeka Malang agar dapat meningkatkan pelayanan dalam memenuhi kebutuhan pengguna aplikasi SIAKAD.

\section{METODE PENELITIAN}

Berdasarkan permasalahan dan tujuannya, penelitian ini akan didesain sebagai penelitian kuantitatif yang akan melibatkan data-data berupa angka atau statistik. Angka-angka tersebut digunakan sebagai representasi atas informasi yang diperoleh dalam penelitian. Dari angka-angka itulah analisis penelitian ini akan dibangun dan disimpulkan. Oleh karena itu, penelitian kuantitatif lebih bersifat deduktif. Penelitian jenis ini berangkat dari lingkup yang khusus menuju lingkup yang lebih umum. Datadata yang diperoleh dari lapangan akan digeneralisasi sebuah kesimpulan umum.

Lingkup penelitian ini berkaitan dengan Manajemen Sistem Informasi khususnya variabel yang mempengaruhi kepuasan pengguna sistem informasi akademik antara lain variabel kualitas sistem, kualitas informasi, kualitas layanan, pada biro administrasi akademik Universitas Merdeka Malang. Penelitian ini dilaksanakan Universitas Merdeka Malang yang beralamatkan Jalan Terusan Dieng No. 62-64, Klojen, Pisang Candi, Sukun, Jawa Timur, 65146, Indonesia. Peneliti memilih Universitas Merdeka Malang karena berbasis IT dan belum ada penelitian Manajemen Sistem Informasi di Universitas Merdeka Malang.

Adapun variabel yang digunakan dalam penelitian ini, antara lain:

a. Variabel Bebas (X)

1. Kualitas Sistem $\left(\mathrm{X}_{1}\right)$

2. Kualitas Informasi $\left(X_{2}\right)$

3. Kualitas Layanan $\left(X_{3}\right)$

b. Variabel Terikat (Y)

1. Kepuasan Pengguna

Definisi serta indikator masing-masing variabel adalah sebagai berikut:

a. Kualitas Sistem, adalah kemampuan atau performa sistem dalam menyediakan informasi sesuai kebutuhan pengguna (DeLone dan McLean, 1992). Indikatornya adalah kemudahan untuk digunakan (ease of use), keandalan sistem (reliability), kecepatan akses (response time), fleksibilitas sistem (flexibility) dan keamanan sistem (security).

b.Kualitas Informasi, merupakan kualitas keluaran (output) berupa informasi yang dihasilkan oleh sistem informasi yang digunakan (Rai et al., 2002). Indikator yang digunakan untuk mengukur kualitas informasi adalah kelengkapan (completeness), penyajian informasi (format), relevan (relevance), akurat (accurate) dan ketepatan waktu (timeliness).

c. Kualitas Layanan, merupakan hasil perbandingan antara persepsi pengguna atas layanan yang mereka inginkan dan terima (Parasuraman et al., 1988). Indikator yang digunakan untuk mengukur kualitas sistem adalah kehandalan (service reliability), daya tangkap (responsiveness), jaminan (assurance), empati (empathy) dan bukti langsung (tangibles).

d.Kepuasan Pengguna, adalah respon pemakai terhadap penggunaan keluaran sistem informasi (Jogiyanto, 2007:23). Indikator yang digunakan untuk mengukur kepuasan pengguna adalah kepuasan sistem, kepuasan informasi dan kepuasan layanan.

Adapun yang menjadi sumber data dalam peneltian ini adalah mahasiswa Universitas 
Merdeka Malang. Jenis data yang dipilih adalah data primer yang berasal dari mahasiswa secara langsung. Untuk memperolehnya, digunakan kuesioner untuk masing-masing responden yang telah berisi pertanyaan-pertanyaan sesuai variabel yang telah ditentukan. Sebagai penunjang, penelitian ini juga memanfaatkan data administratif berupa dokumen-dokumen dari pegawai bagian sistem informasi, seperti laporan dan artikel terkait pokok masalah penelitian ini.

Tujuan penggunaan kuesioner adalah untuk memperoleh data deskriptif sebagai penguji hipotesis. Data dalam kuesioner itu bersifat tertutup. Jawaban responden akan dibatasi dengan memberi beberapa alternatif jawaban, atau mungkin hanya satu jawaban saja (Nasir, 2008:46). Item skala penilaian disusun berdasarkan skala Likert. Skor yang dipakai dalam rentang 1-5. Masing-masing skor diterapkan secara bervariasi sesuai kategori jawaban.

$\begin{array}{lll}\text { a. Sangat Setuju, skor } & 5 \\ \text { b. Setuju, dengan skor } & 4 \\ \text { c. Netral, dengan skor } & 3 \\ \text { d. Tidak Setuju, skor } & 2 \\ \text { e. } & \text { Sangat Tidak Setuju, skor } & 1\end{array}$

e. Sangat Tidak Setuju, skor 1

Sebelum kuesioner digunakan, perlu suatu uji validitas dan reliabilitas untuk menentukan keabsahan data. Uji validitas dilakukan dengan mengkorelasikan skor masing-masing item dengan item total dengan menggunakan korelasi (r) product moment. Rumus yang digunakan adalah sebagai berikut:

$r=\frac{(N \times \Sigma f X Y)-(\Sigma f X \times \Sigma f Y)}{\sqrt{\left(\left(N \Sigma f X^{2}-(\Sigma f X)^{2}\right)\right) \times\left(\left(N \Sigma f Y^{2}-(\Sigma f Y)^{2}\right)\right]}}$

Keterangan : $\mathrm{r}=$ koefisien korelasi; $\mathrm{Y}=$ total skor; $\mathrm{X}^{`}=$ skor item; $\mathrm{N}=$ jumlah responden. Bila skor item signifikan pada tingkat kepercayaan 95\% $(\alpha=0.05)$, bisa dikatakan bahwa item pernyataan valid.

Sementara itu, reliabilitas dalam penelitian ini diarahkan ke jenis internal. Reliabilitas ini diperoleh dengan cara menganalisis data dari satu kali pengetesan (Arikunto 2009:172). Oleh karena instrumen yang digunakan memiliki rentang nilai, maka rumus yang digunakan sebagai berikut:

$$
r=\left(\frac{k}{k-1}\right)\left(1-\frac{\Sigma \sigma_{\mathrm{b}}^{2}}{\sigma_{1}^{2}}\right)
$$

Keterangan : $\mathrm{r}=$ reliabilitas instrumen; $\mathrm{k}=$ banyaknya item pertanyaan; $\sigma_{\mathrm{b}}^{2}$ jumla varian butir; = varian $\sigma_{0}^{2}$ otal. Suatu instrumen dikatakan andal apabila nilai $\mathrm{r}$ lebih besar atau sama dengan 0,6 (Nurgiyantoro, 2006:297).

Populasi data dalam penelitian ini adalah mahasiswa S2 Magister Manajemen Universitas Merdeka Malang yang berjumlah 243 orang. Untuk menetukan sampel penelitian, karena jumlah populasinya besar (>100), digunakan rumus: $\mathrm{n}=25 \% \times \mathrm{N}$. Keterangan: $\mathrm{n}=$ besar sampel; $\mathrm{N}=$ besar populasi. Jadi, $\mathrm{n}=25 \%$ x $243=60,75$ atau 61 orang.

Metode analisis data dalam penelitian ini dilakukan melalui beberapa tahapan, seperti:

a. Analisis deskriptif, dilakukan guna mengetahui gambaran umum tanggapan responden tentang kualitas sistem, kualitas informasi, kualitas layanan, dan kepuasan pengguna. Sasaran analisis adalah frekuensi relatif, rata-rata hitung, nilai maksimum dan minimum dari variabel, indikator, maupun item-item penelitian. Penelitian ini dengan bantuan SPSS 22 for windows.

b.Uji asumsi klasik, dilakukan guna menilai independensi setiap variabel bebas agar diperoleh hasil yang tidak bias. Asumsiasumsi yang harus dipenuhi dalam tahap ini, antara lain: (a) normalitas (variabel pengganggu atau residual dalam model regresi memiliki distribusi normal); heteroskedastisitas (gejala ini terjadi karena terlalu bervariasinya data yang diteliti, namun reliabilitas data harus tetap sama); dan (c) multikolinearitas (syaratnya, nilai variance inflating factor di bawah 5, memiliki angka tolerance mendekati 1 , dan korelasi antar variabel bebas harus di bawah 0,05/lemah).

c. Analisis regresi berganda, digunakan untuk menguji pengaruh sebab akibat antara variabel bebas (X) dan variabel terikat (Y). Model matematis atas fungsi regresi hubungan kedua variabel tersebut adalah:

$$
\mathbf{Y}=\alpha+\boldsymbol{\beta}_{1} \mathbf{X}_{1}+\boldsymbol{\beta}_{2} \mathbf{X}_{2}+\boldsymbol{\beta}_{3} \mathbf{X}_{3}+\varepsilon
$$

Keterangan : $\mathrm{Y}=$ kepuasan pengguna; $\alpha=$ konstansta; $\beta 1, \beta 2, \beta 3=$ koefisien regresi; $X 1=$ kualitas sistem; $\mathrm{X} 2=$ kualitas informasi; $\mathrm{X} 3=$ kualitas layanan; $\varepsilon=$ nilai residu (Gujarati, 1997).

d. Pengujian hipotesis, dilakukan dengan ...

\section{PEMBAHASAN}

\section{Uji Validitas}

Uji validitas dimaksudkan untuk menguji apakah indikator-indikator dalam instrumen dapat mengukur variabel penelitian. Metode yang digunakan untuk uji validitas adalah metode product moment dengan kriteria yaitu 
bila nilai koefisien korelasi ( $\mathrm{r}$ hitung) lebih tinggi daripada $\mathrm{r}$ tabel $(\mathrm{N}=30, \alpha=0,05)$ yaitu 0,361 , maka butir tersebut dapat dikatakan valid. a.Hasil Uji Validitas Instrumen Variabel Kualitas Sistem

Semua item pernyataan untuk indikator Kemudahan untuk digunakan (ease of use), Fleksibilitas sistem (flexibility), Kecepatan akses (response time), Keandalan sistem (reliability) dan Keamanan sistem (security) pada variabel Kualitas Sistem memiliki koefisien korelasi (r-hitung) lebih besar dari $\mathrm{r}$ tabel $(0,361)$. Hal ini menunjukkan bahwa semua aitem pernyataan untuk indikator pada variabel Kualitas Sistem dinyatakan valid.

b. Hasil Uji Validitas Insrumen Variabel Kualitas Informasi

Semua item pernyataan untuk indikator Kelengkapan (completeness), Penyajian Informasi (format), Relevan (relevance), Akurat (accurate) dan Ketepatan Waktu(timeliness) pada variabel Kualitas Informasi memiliki koefisien korelasi ( $\mathrm{r}$ hitung) lebih besar dari $r$ tabel $(0,361)$. Hal ini menunjukkan bahwa semua aitem pernyataan untuk indikator pada variabel Kualitas Informasi dinyatakan valid.

c. Hasil Uji Validitas Insrumen Variabel Kualitas Layanan

Semua item pernyataan untuk indikator Kehandalan (service reliability), Empati (empathy) dan Bukti langsung (tangibles) pada variabel Kualitas Informasi memiliki koefisien korelasi ( $\mathrm{r}$ hitung) lebih besar dari $\mathrm{r}$ tabel $(0,361)$. Hal ini menunjukkan bahwa semua aitem pernyataan untuk indikator pada variabel Kualitas Layanan dinyatakan valid.

d. Hasil Uji Validitas Insrumen Variabel Kepuasan Pengguna

Semua item pernyataan untuk indikator Kepuasan Sistem, Kepuasan Informasi dan Kepuasan Layanan pada variabel Kepuasan Pengguna memiliki koefisien korelasi ( $\mathrm{r}$ hitung) lebih besar dari $r$ tabel $(0,361)$. Hal ini menunjukkan bahwa semua aitem pernyataan untuk indikator pada variabel Kepuasan Pengguna dinyatakan valid.

\section{Uji Reliabilitas}

Uji reliabilitas dimaksudkan untuk menguji apakah instrument tersebut dapat dipercaya untuk mengukur variabel penelitian tersebut, metode yang digunakan untuk uji reliabilitas adalah metode croncbach's alpha dengan kriteria bila nilai alpha $\geq 0,600$ maka instrument dinyatakan reliabel

a. Hasil uji reliabilitas pada variabel Kualitas Sistem menunjukkan bahwa seluruh butir pada variabel Kualitas Sistem dinyatakan reliabel karena memiliki Alpha Cronbach lebih besar sama dengan 0,6 .

b.Hasil uji reliabilitas instrumen pada variabel Kualitas Informasi menunjukkan bahwa seluruh butir pada variabel Kualitas Informasi dinyatakan reliabel karena memiliki Alpha Cronbach lebih besar sama dengan 0,6.

c. Hasil uji reliabilitas instrumen pada variabel Kualitas Layanan menunjukkan bahwa seluruh butir pada variabel Kualitas Layanan dinyatakan reliabel karena memiliki Alpha Cronbach lebih besar sama dengan 0,6.

d.Hasil uji reliabilitas instrument pada variabel Kepuasan Pengguna menunjukkan bahwa seluruh butir pada Variabel Kepuasan Pengguna dinyatakan reliabel karena memiliki Alpha Cronbach lebih besar sama dengan 0,6.

\section{Hasil Analisis Deskriptif}

a. Deskripsi Responden Variabel Kualitas sistem $\left(\mathrm{X}_{1}\right)$ Tanggapan 61 responden pada variabel kualitas sistem dengan indikator kemudahan untuk digunakan (ease of use), keandalan sistem (reliability), kecepatan akses (response time), fleksibilitas sistem (flexibility) dan keamanan sistem (security).

1) Tanggapan Responden untuk indikator Kemudahan yang digunakan (ease of use) pada Kualitas sistem. Indikator Kemudahan untuk digunakan (ease of use) memiliki mean sebesar 4,57, berarti bahwa tanggapan responden terhadap indikator Kemudahan untuk digunakan (ease of use) adalah setuju, hal ini menujukkan bahwa kualitas sistem didukung indikator Kemudahan untuk digunakan (ease of use). Indikator Kemudahan untuk digunakan (ease of use) ini meliputi item-item:

a) Aitem pernyataan Saya dapat menghemat waktu pekerjaan dengan menggunakan SIAKAD memperoleh mean skor sebesar 4,57 hal ini bermakna bahwa pegawai setuju dalam menghemat waktu pekerjaan dengan menggunakan SIAKAD. Adapun penyebaran pernyataan responden $51 \%$ menyatakan sangat setuju, 39\% menyatakan setuju, $7 \%$ menyatakan netral, 3\% menyatakan tidak setuju, 
serta $0 \%$ menyatakan sangat tidak setuju.

b) Aitem pernyataan Saya dapat mempermudah pekerjaan dengan menggunakan SIAKAD memperoleh mean skor sebesar 4,57 hal ini bermakna bahwa pegawai setuju dalam mempermudah pekerjaan dengan menggunakan SIAKAD. Adapun penyebaran pernyataan responden $52 \%$ menyatakan sangat setuju $36 \%$ menyatakan setuju, $8 \%$ menyatakan netral, 3\% menyatakan tidak setuju, serta $0 \%$ menyatakan sangat tidak setuju.

2) Tanggapan Responden untuk indikator Fleksibilitas sistem (flexibility) pada Kualitas sistem. Indikator Fleksibilitas sistem (flexibility) memiliki mean sebesar 4,7, berarti bahwa tanggapan responden terhadap indikator Fleksibilitas sistem (flexibility) adalah setuju, hal ini menujukkan bahwa kualitas sistem didukung indikator Fleksibilitas sistem (flexibility). Indikator Fleksibilitas sistem (flexibility) ini meliputi item-item:

a) Aitem pernyataan Saya dapat mengakses SIAKAD dimanapun berada memperoleh mean skor sebesar 4,63 hal ini bermakna bahwa pegawai setuju dalam mengakses SIAKAD dimanapun berada. Adapun penyebaran pernyataan responden $49 \%$ menyatakan sangat setuju, $33 \%$ menyatakan setuju, $8 \%$ menyatakan netral, $2 \%$ menyatakan tidak setuju, serta $0 \%$ menyatakan sangat tidak setuju.

b) Aitem pernyataan Saya dapat mengakses SIAKAD dengan menggunakan perangkat apapun memperoleh mean skor sebesar 4,77 hal ini bermakna bahwa pegawai setuju dalam mengakses SIAKAD dengan menggunakan perangkat apapun. Adapun penyebaran pernyataan responden $64 \%$ menyatakan sangat setuju, 26\% menyatakan setuju, $8 \%$ menyatakan netral, $2 \%$ menyatakan tidak setuju, serta $0 \%$ menyatakan sangat tidak setuju.

3) Tanggapan Responden untuk indikator Kecepatan akses (response time) pada Kualitas sistem. Indikator Kecepatan akses memiliki mean sebesar 4,13 , berarti bahwa tanggapan responden terhadap indikator Kecepatan akses adalah setuju, hal ini menujukkan bahwa kualitas sistem didukung indikator Kecepatan akses, yang meliputi:

a) Aitem pernyataan Dalam penggunaan SIAKAD, proses mengakses data cepat memperoleh mean skor sebesar 4,27 hal ini bermakna bahwa pegawai setuju dalam penggunaan SIAKAD, proses mengakses data cepat. Adapun penyebaran pernyataan responden $43 \%$ menyatakan sangat setuju, $41 \%$ menyatakan setuju, $13 \%$ menyatakan netral, 3\% menyatakan tidak setuju, serta $0 \%$ menyatakan sangat tidak setuju.

b) Aitem pernyataan Dalam penggunaan SIAKAD, proses mengunduh data cepat memperoleh mean skor sebesar 4,10 hal ini bermakna bahwa pegawai setuju dalam penggunaan SIAKAD, proses mengunduh data cepat. Adapun penyebaran pernyataan responden $34 \%$ menyatakan sangat setuju, $46 \%$ menyatakan setuju, $15 \%$ menyatakan netral, 5\% menyatakan tidak setuju, serta $0 \%$ menyatakan sangat tidak setuju.

c) Aitem pernyataan Dalam penggunaan SIAKAD, proses mengunggah data cepat memperoleh mean skor sebesar 4,03 hal ini bermakna bahwa pegawai setuju dalam penggunaan SIAKAD, proses mengunggah data cepat. Adapun penyebaran pernyataan responden 33\% menyatakan sangat setuju, $44 \%$ menyatakan setuju, $18 \%$ menyatakan netral, 5\% menyatakan tidak setuju, serta $0 \%$ menyatakan sangat tidak setuju.

4) Tanggapan Responden untuk indikator Keandalan sistem (reliability) pada Kualitas system. Indikator Keandalan sistem memiliki mean sebesar 3,54, berarti bahwa tanggapan responden terhadap indikator Keandalan sistem adalah setuju, hal ini menujukkan bahwa kualitas sistem didukung indikator Keandalan sistem, yang meliputi:

a) Aitem pernyataan Jaringan tidak mudah down saat saya menggunakan SIAKAD memperoleh mean skor sebesar 3,53 hal ini bermakna bahwa pegawai setuju dalam jaringan tidak mudah down saat saya menggunakan SIAKAD. Adapun penyebaran pernyataan responden $18 \%$ menyatakan sangat setuju $39 \%$ menyatakan setuju, 30\% menyatakan 
netral, 13\% menyatakan tidak setuju, serta $0 \%$ menyatakan sangat tidak setuju.

b) Aitem pernyataan Terdapat back up (cadangan) data saat saya mengakses SIAKAD memperoleh mean skor sebesar 3,50, hal ini bermakna bahwa pegawai setuju dalam Terdapat back up (cadangan) data saat saya mengakses SIAKAD. Adapun penyebaran pernyataan responden $18 \%$ menyatakan sangat setuju $30 \%$ menyatakan setuju, $43 \%$ menyatakan netral, $10 \%$ menyatakan tidak setuju, serta $0 \%$ menyatakan sangat tidak setuju.

c) Aitem pernyataan Proses recovery cepat ketika mengakses memperoleh mean skor sebesar 3,60 hal ini bermakna bahwa pegawai setuju dalam Proses recovery cepat ketika mengakses. Adapun penyebaran pernyataan responden $18 \%$ menyatakan sangat setuju 33\% menyatakan setuju, 38\% menyatakan netral, $11 \%$ menyatakan tidak setuju, serta $0 \%$ menyatakan sangat tidak setuju.

5) Tanggapan Responden untuk indikator Keamanan sistem (security) pada Kualitas system. Indikator Keamanan sistem memiliki mean sebesar 4,23, berarti bahwa tanggapan responden terhadap indikator Keamanan sistem adalah setuju, hal ini menujukkan bahwa kualitas sistem didukung indikator Keamanan sistem yang meliputi:

a) Aitem pernyataan Dalam mengakses SIAKAD kerahasiaan data saya terjamin aman memperoleh mean skor sebesar 4,27 hal ini bermakna bahwa pegawai setuju dalam mengakses SIAKAD kerahasiaan data saya terjamin aman. Adapun penyebaran pernyataan responden $38 \%$ menyatakan sangat setuju $43 \%$ menyatakan setuju, $16 \%$ menyatakan netral, 3\% menyatakan tidak setuju, serta $0 \%$ menyatakan sangat tidak setuju.

b) Aitem pernyataan Saat saya mengakses SIAKAD, data tidak mudah di hack (bajak) memperoleh mean skor sebesar 4,20 hal ini bermakna bahwa pegawai setuju dalam mengakses SIAKAD data tidak mudah di hack (bajak). Adapun penyebaran pernyataan responden $36 \%$ menyatakan sangat setuju $41 \%$ menyatakan setuju, 20\% menyatakan netral, 3\% menyatakan tidak setuju, serta $0 \%$ menyatakan sangat tidak setuju.

b. Deskripsi Responden Variabel Kualitas informasi $\left(\mathrm{X}_{2}\right)$

Tanggapan 61 responden pada variabel kualitas informasi dengan indikator kelengkapan (completeness), penyajian informasi (format), relevan (relevance), akurat (accurate) dan ketepatan waktu (timeliness).

1) Tanggapan Responden untuk indikator kelengkapan (completeness) pada Kualitas informasi. Indikator kelengkapan (completeness) memiliki mean sebesar 4,28, berarti bahwa tanggapan responden terhadap indikator kelengkapan (completeness) adalah setuju, hal ini menujukkan bahwa Kualitas informasi didukung indikator kelengkapan (completeness). Indikator kelengkapan (completeness) ini meliputi item-item:

a) Saya dapat mengakses Informasi yang disajikan dalam SIAKAD memperoleh mean skor sebesar 4,23 hal ini bermakna bahwa pegawai setuju dalam mengakses Informasi yang disajikan dalam SIAKAD. Adapun penyebaran pernyataan responden $36 \%$ menyatakan sangat setuju $38 \%$ menyatakan setuju, $23 \%$ menyatakan netral, $3 \%$

menyatakan tidak setuju, serta $0 \%$ menyatakan sangat tidak setuju.

b) Saya dapat mengakses data yang disajikan SIAKAD sesuai kebutuhan memperoleh mean skor sebesar 4,33 hal ini bermakna bahwa pegawai setuju dalam mengakses data yang disajikan SIAKAD sesuai kebutuhan. Adapun penyebaran pernyataan responden $41 \%$ menyatakan sangat setuju $38 \%$ menyatakan setuju, $18 \%$ menyatakan netral, $3 \%$ menyatakan tidak setuju, serta $0 \%$ menyatakan sangat tidak setuju.

2) Tanggapan Responden untuk indikator penyajian informasi (format) pada Kualitas informasi. Indikator penyajian informasi (format) memiliki mean sebesar 3,65, berarti bahwa tanggapan responden terhadap indikator penyajian informasi (format) adalah setuju, hal ini menujukkan bahwa kualitas sistem didukung indikator 
penyajian informasi (format). Indikator penyajian informasi (format) ini meliputi item-item:

a) Aitem pernyataan Dalam mengakses SIAKAD informasi yang disajikan mudah dibaca pengguna memperoleh mean skor sebesar 4,27 hal ini bermakna bahwa pegawai setuju dalam mengakses SIAKAD informasi yang disajikan mudah dibaca pengguna. Adapun penyebaran pernyataan responden $34 \%$ menyatakan sangat setuju $41 \%$ menyatakan setuju, 20\% menyatakan netral, 5\% menyatakan tidak setuju, serta $0 \%$ menyatakan sangat tidak setuju.

b) Aitem pernyataan Dalam mengakses SIAKAD terdapat manual book untuk membantu. memperoleh mean skor sebesar 3,03 hal ini bermakna bahwa pegawai setuju dalam mengakses SIAKAD terdapat manual book untuk membantu. Adapun penyebaran pernyataan responden $10 \%$ menyatakan sangat setuju $18 \%$ menyatakan setuju, $25 \%$ menyatakan netral, $26 \%$ menyatakan tidak setuju, serta $21 \%$ menyatakan sangat tidak setuju.

3) Tanggapan Responden untuk indikator $X_{23}$ : relevan (relevance) pada Kualitas informasi. Indikator relevan (relevance) memiliki mean sebesar 3,98, berarti bahwa tanggapan responden terhadap indikator relevan (relevance) adalah setuju, hal ini menujukkan bahwa kualitas sistem didukung indikator relevan (relevance). Indikator relevan (relevance) ini meliputi item-item:

a) Aitem pernyataan Saya mendapatkan informasi sesuai dengan kebutuhan memperoleh mean skor sebesar 3,90 hal ini bermakna bahwa pegawai setuju dalam mendapatkan informasi sesuai dengan kebutuhan. Adapun penyebaran pernyataan responden $30 \%$ menyatakan sangat setuju $41 \%$ menyatakan setuju, $25 \%$ menyatakan netral, $5 \%$ menyatakan tidak setuju, serta $0 \%$ menyatakan sangat tidak setuju.

b) Aitem pernyataan Saya mendapatkan informasi yang up to date (terbaru) memperoleh mean skor sebesar 4,07, hal ini bermakna bahwa pegawai setuju dalam mendapatkan informasi yang up to date (terbaru). Adapun penyebaran pernyataan responden $36 \%$ menyatakan sangat setuju $36 \%$ menyatakan setuju,
$25 \%$ menyatakan netral, $3 \%$ menyatakan tidak setuju, serta $0 \%$ menyatakan sangat tidak setuju.

4) Tanggapan Responden untuk indikator akurat (accurate) pada Kualitas informasi. Indikator akurat (accurate) memiliki mean sebesar 4,25, berarti bahwa tanggapan responden terhadap indikator akurat (accurate) adalah setuju, hal ini menujukkan bahwa kualitas sistem didukung indikator akurat (accurate). Indikator akurat (accurate) ini meliputi item-item:

a) Aitem pernyataan Data yang saya dapat dari SIAKAD tepat dan akurat memperoleh mean skor sebesar 4,20, hal ini bermakna bahwa pegawai setuju dalam SIAKAD tepat dan akurat. Adapun penyebaran pernyataan responden $44 \%$ menyatakan sangat setuju 30\% menyatakan setuju, 21\% menyatakan netral, 5\% menyatakan tidak setuju, serta $0 \%$ menyatakan sangat tidak setuju.

b) Aitem pernyataan Data yang saya dapat dari SIAKAD sesuai dengan kebutuhan memperoleh mean skor sebesar 4,30, hal ini bermakna bahwa pegawai setuju dalam SIAKAD sesuai dengan kebutuhan. Adapun penyebaran pernyataan responden $44 \%$ menyatakan sangat setuju 34\% menyatakan setuju, $18 \%$ menyatakan netral, $3 \%$ menyatakan tidak setuju, serta $0 \%$ menyatakan sangat tidak setuju.

5) Tanggapan Responden untuk indikator ketepatan waktu (timeliness) pada Kualitas informasi. Indikator akurat (accurate) memiliki mean sebesar 3,94, berarti bahwa tanggapan responden terhadap indikator ketepatan waktu (timeliness) adalah setuju, hal ini menujukkan bahwa kualitas sistem didukung indikator ketepatan waktu (timeliness). ketepatan waktu (timeliness) ini meliputi item-item:

a) Aitem pernyataan Dalam mengakses SIAKAD penyampaian informasi ke saya tepat waktu memperoleh mean skor sebesar 3,94, hal ini bermakna bahwa pegawai setuju dalam SIAKAD penyampaian informasi ke saya tepat waktu. Adapun penyebaran pernyataan responden $38 \%$ menyatakan sangat setuju $41 \%$ menyatakan setuju, $16 \%$ menyatakan netral, 5\% menyatakan tidak 
setuju, serta $0 \%$ menyatakan sangat tidak setuju.

c. Deskripsi Responden Variabel Kepuasan Pengguna $\left(\mathrm{Y}_{1}\right)$

Tanggapan 61 responden pada variabel kepuasan pengguna dengan indikator kepuasan sistem, kepuasan informasi dan kepuasan layanan.

1) Tanggapan Responden untuk indikator Kepuasan Sistem pada Kepuasan Pengguna. Indikator Kepuasan Sistem memiliki mean sebesar 4,21, berarti bahwa tanggapan responden terhadap indikator Kepuasan sistem adalah setuju, hal ini menujukkan bahwa Kepuasan Pengguna didukung indikator Kepuasan Sistem. Indikator Kepuasan Sistem ini meliputi item-item:

a) Aitem pernyataan Saya puas dengan SIAKAD karena dapat mempermudah pekerjaan. memperoleh mean skor sebesar 4,33, hal ini bermakna bahwa pegawai setuju dalam puas dengan SIAKAD karena dapat mempermudah pekerjaan. Adapun penyebaran pernyataan responden $41 \%$ menyatakan sangat setuju $44 \%$ menyatakan setuju, $11 \%$ menyatakan netral, $3 \%$ menyatakan tidak setuju, serta $0 \%$ menyatakan sangat tidak setuju.

b) Aitem pernyataan Saya puas dengan SIAKAD karena dapat mengakses SIAKAD dimanapun berada memperoleh mean skor sebesar 4,57, hal ini bermakna bahwa pegawai setuju dalam puas dengan SIAKAD karena dapat mengakses SIAKAD dimanapun berada. Adapun penyebaran pernyataan responden $46 \%$ menyatakan sangat setuju $41 \%$ menyatakan setuju, $8 \%$ menyatakan netral, $5 \%$ menyatakan tidak setuju, serta $0 \%$ menyatakan sangat tidak setuju.

c) Aitem pernyataan Saya puas dengan SIAKAD karena proses akses data cepat memperoleh mean skor sebesar 4,43, hal ini bermakna bahwa pegawai setuju dalam puas dengan SIAKAD karena proses akses data cepat. Adapun penyebaran pernyataan responden $41 \%$ menyatakan sangat setuju $43 \%$ menyatakan setuju, 13\% menyatakan netral, $0 \%$ menyatakan tidak setuju, serta $0 \%$ menyatakan sangat tidak setuju.

d) Aitem pernyataan Saya puas dengan SIAKAD karena terdapat back up (cadangan) data memperoleh mean skor sebesar 3,87, hal ini bermakna bahwa pegawai setuju dalam puas dengan SIAKAD karena terdapat back up (cadangan) data. Adapun penyebaran pernyataan responden $23 \%$ menyatakan sangat setuju $51 \%$ menyatakan setuju, $23 \%$ menyatakan netral, $3 \%$ menyatakan tidak setuju, serta $0 \%$ menyatakan sangat tidak setuju.

e) Aitem pernyataan Saya puas dengan SIAKAD karena susah di hack (bajak) memperoleh mean skor sebesar 3,87, hal ini bermakna bahwa pegawai setuju dalam puas dengan SIAKAD karena susah di hack (bajak). Adapun penyebaran pernyataan responden $33 \%$ menyatakan sangat setuju $39 \%$ menyatakan setuju, $23 \%$ menyatakan netral, 5\% menyatakan tidak setuju, serta $0 \%$ menyatakan sangat tidak setuju.

2) Tanggapan Responden untuk indikator Kepuasan Informasi pada Kepuasan Pengguna. Indikator Kepuasan Informasi memiliki mean sebesar 4,46, berarti bahwa tanggapan responden terhadap indikator Kepuasan Informasi adalah setuju, hal ini menujukkan bahwa Kepuasan pengguna didukung indikator Kepuasan Informasi. Indikator Kepuasan Informasi ini meliputi item-item:

a) Aitem pernyataan Saya puas dengan SIAKAD karena informasi yang disajikan lengkap memperoleh mean skor sebesar 4,33, hal ini bermakna bahwa pegawai setuju dalam puas dengan SIAKAD karena informasi yang disajikan lengkap. Adapun penyebaran pernyataan responden $46 \%$ menyatakan sangat setuju 39\% menyatakan setuju, $13 \%$ menyatakan netral, $2 \%$ menyatakan tidak setuju, serta $0 \%$ menyatakan sangat tidak setuju.

b) Aitem pernyataan Saya puas dengan SIAKAD karena informasi yang disajikan mudah dibaca memperoleh mean skor sebesar 4,57, hal ini bermakna bahwa pegawai setuju dalam puas dengan SIAKAD karena informasi yang disajikan mudah dibaca. Adapun 
penyebaran pernyataan responden 57\% menyatakan sangat setuju $30 \%$ menyatakan setuju, $11 \%$ menyatakan netral, $2 \%$ menyatakan tidak setuju, serta $0 \%$ menyatakan sangat tidak setuju.

c) Aitem pernyataan Saya puas dengan SIAKAD karena memperoleh informasi sesuai dengan kebutuhan memperoleh mean skor sebesar 4,63, hal ini bermakna bahwa pegawai setuju dalam puas dengan SIAKAD karena memperoleh informasi sesuai dengan kebutuhan. Adapun penyebaran pernyataan responden $62 \%$ menyatakan sangat setuju 25\% menyatakan setuju, $11 \%$ menyatakan netral, $2 \%$ menyatakan tidak setuju, serta $0 \%$ menyatakan sangat tidak setuju.

d) Aitem pernyataan Saya puas dengan SIAKAD karena mendapat data tepat dan akurat memperoleh mean skor sebesar 4,47, hal ini bermakna bahwa pegawai setuju dalam puas dengan SIAKAD karena mendapat data tepat dan akurat. Adapun penyebaran pernyataan responden $49 \%$ menyatakan sangat setuju $36 \%$ menyatakan setuju, $13 \%$ menyatakan netral, $2 \%$ menyatakan tidak setuju, serta $0 \%$ menyatakan sangat tidak setuju.

e)Aitem pernyataan Saya puas dengan SIAKAD karena penyampaian informasi tepat waktu memperoleh mean skor sebesar 4,30, hal ini bermakna bahwa pegawai setuju dalam puas dengan SIAKAD karena penyampaian informasi tepat waktu. Adapun penyebaran pernyataan responden $49 \%$ menyatakan sangat setuju $34 \%$ menyatakan setuju, $13 \%$ menyatakan netral, $3 \%$ menyatakan tidak setuju, serta $0 \%$ menyatakan sangat tidak setuju.

3) Tanggapan Responden untuk indikator Kepuasan Layanan pada Kepuasan Pengguna. Indikator Kepuasan Layanan memiliki mean sebesar 4,43 , berarti bahwa tanggapan responden terhadap indikator Kepuasan Layanan adalah setuju, hal ini menujukkan bahwa Kepuasan Pengguna didukung indikator Kepuasan Layanan. Indikator Kepuasan Layanan ini meliputi item-item:

a)Aitem pernyataan Saya puas dengan SIAKAD karena saya menguasai permasalahan yang ada memperoleh mean skor sebesar 4,43, hal ini bermakna bahwa pegawai setuju dalam puas dengan SIAKAD karena teknisi menguasai permasalahan yang ada. Adapun penyebaran pernyataan responden $57 \%$ menyatakan sangat setuju $28 \%$ menyatakan setuju, $11 \%$ menyatakan netral, $3 \%$ menyatakan tidak setuju, serta $0 \%$ menyatakan sangat tidak setuju.

\section{Uji Asumsi Klasik}

Untuk menilai independensi setiap variabel bebas maka perlu memenuhi asumsi-asumsi klasik agar diperoleh hasil yang tidak bias atau dengan kata lain untuk mengetahui apakah estimator-estimator pengujian tersebut bersifat BLUE (Best Linear Unbias Estimator) atau tidak. Efisien dari model analisis regresi berganda dengan metode kuadrat terkecil atau OLS (Ordinary Least Square) terhadap tiga atau lebih variabel yang dinamai (Gujarati, 1997:46). Adapun asumsi-asumsi yang harus dipenuhi adalah :

a. Uji Normalitas

Dasar pengambilan keputusan dalam deteksi normalitas menurut Ghozali (2007: 112) adalah: (1) jika data menyebar di sekitar garis diagonal dan mengikuti arah garis diagonal atau grafik histogramnya maka model regresi tersebut memenuhi asumsi normalitas; (2) Jika data menyebar jauh dari diagonal atau tidak mengikuti arah garis diagonal atau grafik histogram maka model regresi tersebut tidak memenuhi asumsi normalitas.

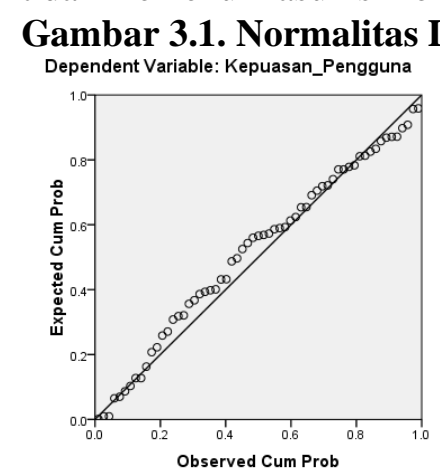

Gambar 3.1. menunjukkan bahwa data (titik) menyebar di sekitar dan mendekati garis diagonal. Ini menunjukkan bahwa data penelitian yang mencakup variabel kualitas system, kualitas informasi dan kualitas layanan berdistribusi normal.

b. Uji Heteroskedastisitas 
Setiap observasi mempunyai reliabilitas yang sama. Gejala heteroskedastisitas ini terjadi karena terlalu bervariasinya data yang diteliti. Untuk mendeteksi gejala ini, dilakukan dengan uji korelasi ranking Spearman. Apabila koefisien korelasi ranking Spearman lebih besar dibandingkan dengan nilai kritisnya $(0,05)$, berarti ada gejala heteroskedastisitas. Sebaliknya apabila nilai korelasi Spearman lebih kecil dari nilai kritisnya, maka berarti tidak terjadi gejala heteroskedastisitas.

\section{Gambar 3.2. Uji Heteroskedastisitas}

Dependent Variable: Kepuasan_Pengguna

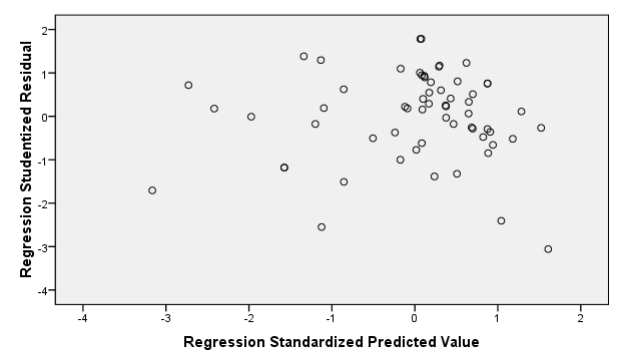

Berdasarkan Gambar 3.2, terlihat titik-titik menyebar secara acak, tidak membentuk sebuah pola tertentu yang jelas, serta tersebar baik di atas maupun di bawah angka 0 pada sumbu Y. Hal ini berarti tidak terjadi heteroskedastisitas pada model regresi.

\section{Analisis Regresi Berganda}

Berdasarkan tabel hasil rekapitulasi hasil analisis regresi berganda diatas, maka diperoleh persamaan regresi berganda sebagai berikut:

$$
\mathrm{Y}=2,565+0,322 \mathrm{X}_{1}+0,444 \mathrm{X}_{2}+0,165 \mathrm{X}_{3}+
$$

Persamaan regresi berganda diatas tersebut dijelaskan sebagai berikut:

$\alpha=2,565$ adalah konstanta. Hal ini menunjukkan bahwa saat variabel bebas Kualitas Sistem (X1), Kualitas Informasi (X2), dan Kualitas Layanan (X3) bernilai 0 (nol) maka variabel terikat Kepuasan Pengguna $(\mathrm{Y})$ bernilai 2,565. b1 $=0,322$ adalah besarnya koefisien regresi variabel bebas Kualitas Sistem (X1). Koefisien regresi bernilai positif menunjukkan bahwa kualitas sistem berpengaruh positif terhadap kepuasaan pengguna. Semakin baik kualitas sistem akan menyebabkan kepuasaan pengguna mengalami peningkatkan, dengan anggapan Kualitas Informasi (X2) dan Kualitas Layanan (X3) besarnya tetap. Pengaruh Kualitas Sistem (X1) terhadap Kepuasan Pengguan (Y) sebesar 0,322. b2 $=0,444$ adalah besarnya koefisien regresi variabel bebas Kualitas Informasi (X2). Koefisien regresi bernilai positif menunjukkan bahwa kualitas informasi berpengaruh positif terhadap kepuasaan pengguna. Semakin baik kualitas informasi akan menyebabkan kepuasaan pengguna mengalami peningkatkan, dengan anggapan Kualitas Sistem (X1) dan Kualitas Layanan (X3) besarnya tetap. Pengaruh Kualitas Informasi (X2) terhadap Kepuasan Pengguan (Y) sebesar 0,444.

b3 $=0,165$ adalah besarnya koefisien regresi variabel bebas Kualitas Layanan (X3). Koefisien regresi bernilai positif menunjukkan bahwa kualitas layanan berpengaruh positif terhadap kepuasaan pengguna. Semakin baik kualitas layanan akan menyebabkan kepuasaan pengguna mengalami peningkatkan, dengan anggapan Kualitas Sistem (X1) dan Kualitas Informasi (X2) besarnya tetap. Pengaruh Kualitas Layanan (X3) terhadap Kepuasan Pengguan (Y) sebesar 0,165.

Nilai koefisien korelasi berganda (R) sebesar 0.846 menunjukkan adanya hubungan yang kuat antara variabel Kualitas Sistem (X1), Kualitas Informasi (X2), Kualitas Layanan (X3), secara bersama-sama dengan Variabel Kepuasan Pengguna (Y).

Dari hasil perhitungan regresi linier berganda pada tabel 17 diatas, diketahui nilai koefisien determinasi $(R)$ sebesar 0,846. Koefisien determinasi ini mempunyai arti bahwa variabel Kualitas Sistem (X1), Kualitas Informasi (X2) dan Kualitas Layanan (X3) secara bersama-sama mampu memberikan kontribusi terhadap variabel Kepuasan Pengguna (Y) sebesar $84,6 \%$, sedangkan sisanya sebesar $16,4 \%$ disebabkan oleh variabel lain yang tidak dimasukkan dalam penelitian ini.

\section{Uji Hipotesis}

a. Pengujian Hipotesis Pertama

1) Uji F. Dari hasil perhitungan analisis regresi berganda dengan SPSS diperoleh $F$ hitung sebesar 47,716. F tabel pada $\alpha=$ $5 \%, \mathrm{df}_{1}=3$ dan $\mathrm{df}_{2}=57$ sebesar 2,77 . Hal ini berarti $\mathrm{F}$ hitung $(47,716)>\mathrm{F}$ tabel $(2,77)$ sedangkan nilai probabilitasnya lebih kecil dari $\alpha(0,000<0,05)$, maka H0 ditolak dan $\mathrm{H} 1$ diterima, berarti variabel bebas Kualitas Sistem, Kualitas Informasi dan Kualitas Layanan berpengaruh secara simultan dan signifikan terhadap 
Kepuasan Pengguna di Universitas Merdeka Malang.

b. Pengujian Hipotesis Kedua

1) Uji t. Hasil dari uji ini dijelaskan sebagai berikut:

a) Variabel Kualitas Sistem (X1). Hasil analisis regresi linier berganda diperoleh nilai t hitung sebesar 2,951 dan t tabel sebesar 1,99 sehingga $\mathrm{t}$ hitung $>\mathrm{t}$ tabel dan nilai signifikasi $(0,000)<\alpha(0,05)$ jadi $\mathrm{H} 0$ ditolak dan $\mathrm{H} 1$ diterima. Dengan demikian terbukti variabel Kualitas Sistem (X1) berpengaruh terhadap Kepuasan Pengguna (Y).

b) Variabel Kualitas Informasi (X2). Hasil analisis regresi linier berganda diperoleh nilai t hitung sebesar 3,739 dan $\mathrm{t}$ tabel sebesar 1,99 sehingga $\mathrm{t}$ hitung $>\mathrm{t}$ tabel dan nilai signifikasi $(0,001)<\alpha(0,05)$ jadi H0 ditolak dan H1 diterima. Dengan demikian terbukti variabel Kualitas Informasi (X2) berpengaruh terhadap Kepuasan Pengguna (Y).

c) Variabel Kualitas Layanan (X3). Hasil analisis regresi linier berganda diperoleh nilai t hitung sebesar 1,547 dan t tabel sebesar 1,99 sehingga $t$ hitung $<\mathrm{t}$ tabel dan nilai signifikasi $(0,127)>\alpha(0,05)$ jadi H0 diterima dan $\mathrm{H} 1$ ditolak. Dengan demikian terbukti variabel Kualitas Layanan (X3) tidak berpengaruh terhadap Kepuasan Pengguna (Y).

c. Pengujian Hipotesis Ketiga

Berdasarkan hasil analisis uji regresi berganda, dapat diketahui bahwa koefisien regresi terbesar yaitu Kualitas layanan $\left(\mathrm{X}_{2}\right)$ sebesar 0,444. Hal ini berarti Kualitas layanan $\left(\mathrm{X}_{2}\right)$ merupakan variabel yang berpengaruh dominan terhadap Kepuasan pengguna (Y). Selanjunya diikuti variabel Kualitas sistem $\left(\mathrm{X}_{1}\right)$ sebesar 0,322, dan variabel Kualitas informasi $\left(\mathrm{X}_{3}\right)$ sebesar 0,165 .

\section{KESIMPULAN}

Tujuan dilakukannya penelitian ini adalah untuk mengetahui pengaruh kualitas sistem, kualitas informasi, dan kualitas layanan terhadap kepuasan pengguna dengan menggunakan pengujian hipotesis pengaruh variabel independen terhadap variabel dependen secara simultan, pengujian hipotesis pengaruh variabel independen terhadap variabel dependen secara parsial dan untuk mengetahui variabel yang paling dominan mempengaruhi kepuasasan pengguna.

1. Pengaruh kualitas sistem, kualitas informasi dan kualitas layanan terhadap kepuasan pengguna secara simultan. Nilai koefisien determinasi $(R)$ sebesar 0,846 menunjukkan bahwa kualitas sistem, kualitas informasi dan kualitas layanan secara bersama-sama mampu memberikan kontribusi terhadap kepuasan pengguna sebesar $84,6 \%$, sedangkan sisanya sebesar $16,4 \%$ disebabkan oleh variabel lain yang tidak dimasukkan dalam penelitian ini. Dari hasil uji F menunjukkan bahwa kualitas sistem, kualitas informasi dan kualitas layanan berpengaruh secara simultan terhadap kepuasan pengguna SIAKAD Universitas Merdeka Malang. Hasil penelitian ini mendukung hasil penelitian wahyudi et al.,(2015) yang menyatakan bahwa kualitas sistem, kualitas informasi dan kualitas layanan berpengaruh terhadap kepuasan pengguna secara simultan.

2. Pengaruh kualitas sistem, kualitas informasi dan kualitas layanan terhadap kepuasan pengguna secara parsial. Dari hasil uji regresi diketahui variabel kualitas sitem memiliki koefisien regresi 0,322. Hal ini menunjukkan bahwa saat variabel kualitas sistem bernilai satu satuan maka variabel kepuasan pengguna bernilai 0,322. Variabel kualitas informasi memiliki koefisien regresi sebesar 0,444 yang menunjukkan bahwa setiap saat variabel kualitas informasi bernilai satu satuan maka kepuasan pengguna bernilai 0,444. Variabel kualitas layanan memiliki koefisien regresi sebesar 0,165 menunjukkan bahwa saat variabel kualitas layanan satu satuan maka kepuasan pengguna bernilai 0,165. Dari hasil uji $\mathrm{F}$ menunjukkan bahwa kualitas sistem, kualitas informasi dan kualitas layanan berpengaruh secara parsial terhadap kepuasan pengguna SIAKAD Universitas Merdeka Malang. Hasil penelitian ini mendukung hasil penelitian Amalia et al.,(2016) yang menyatakan bahwa kualitas sistem berpengaruh terhadap kepuasan pengguna. Penelitian lain Ardianto et al.,(2014) yang menyatakan bahwa kepuasan informasi berpengaruh terhadap kepuasan pengguna. Selanjutnya penelitian Akhmad Ndori (2015) menghasilkan kualitas layanan berpengaruh terhadap kepuasan pengguna.

3. Kualitas informasi sebagai variabel yang paling dominan. Nilai koefisien regresi dari $\mathrm{X} 1=0,322, \quad \mathrm{X} 2=0,444$ dan $\mathrm{X} 3=0,165$. 
Berdasarkan data diatas dapat disimpulkan bahwa Kualitas informasi $\left(\mathrm{X}_{2}\right)$ merupakan variabel yang berpengaruh dominan terhadap Kepuasan pengguna (Y). Selanjunya diikuti variabel Kualitas sistem $\left(\mathrm{X}_{1}\right)$ dan variabel Kualitas layanan $\left(\mathrm{X}_{3}\right)$. Dapat diartikan bahwa untuk meningkatkan kepuasan pengguna sistem informasi akademik pihak Staf IT perlu meningkatkan kualitas informasi yang diberikan kepada Mahasiswa Magister Manajemen Universitas Merdeka Malang.

\section{DAFTAR PUSTAKA}

Amalia, Syara Mutiara \& Dudi Pratomo.2016. Pengaruh Kualitas Sistem Informasi, Kualitas Informasi, Dan Perceived Usefulness Terhadap Kepuasan Pengguna Sistem Informasi Akuntansi(Studi Pada Pengguna Sistem Informasi Akuntansi Di Rumah Sakit Mata Cicendo Bandung). Prodi S1 Akuntansi, Fakultas Ekonomi dan Bisnis, Universitas Telkom.Bandung.

Ardianto, Y.T et al., (2013). "An Empirical Internal Perceptions Study of the Implementation Supply Chain Management in Indonesian Manufacturing Companies As a Mediating Factor of Information Technology Utilization to Organization Performances". European Journal of Business and Management. Vol.5, No.16, 2013

Ardianto, Agung, Silmi Fauziati, \& Eko Nugroho.2014. Faktor-Faktor Yang Mempengaruhi Kepuasan Pengguna Akhir Sistem Informasi Sumber Daya Manusia (Studi Kasus di BPK-RI).

Arikunto, Suharsimi. 2009. Prosedur Penelitian Suatu Pendekatan Praktis. Bina Aksara. Jakarta.

Cravens, D.W. and Piercy, N.F.2006. Strategic Marketing, (8thed.). NY: Mc Graw Hill.

Davis, Fred D., 1989, "Perceived Usefulness, Perceived Ease of Use, and User Acceptance of Information
Technology", MIS Quarterly, September, pp.319- 340.

DeLone, W. H., McLean, E. R. 1992. Information Systems Success: The Quest for the Dependent Variable. Inf. Syst. Res., vol. 3, no. 4,:60-95. 2003. The DeLone and McLean Model of Information Systems Success: A Ten-Year Update. J. Manag. Inf. Syst. Vol. 19(4): 9-30.

Gujarati, 1997. Statistik Ekonometrika. Jakarta : Bumi Aksara

Jogiyanto, HM. 2005. Analisis \& Desain Sistem Informasi: Pendekatan Terstruktur, Teori, dan Aplikasi Bisnis, Edisi Ketiga. Yogyakarta: Andi.

2007. Model Kesuksesan Sistem

Teknologi Informasi. Yogyakarta: Andi.

Nasir, Moch, 2008. Metode Penelitian. Jakarta : Ghalia Indonesia.

Ndori, Akhmad .2015. Pengaruh Sistem Informasi Akademik Dan Kualitas Layanan Terhadap Kepuasan Mahasiswa Di Politeknik Ilmu Pelayaran Semarang. J. Sain dan Tek. Maritim Vol. XIII No.2.

Rai, A., Lang, S.S. and Welker, R.B. 2002. Assessing the Validity of IS SuccessModels: An Empirical Test and Theoretical Analysis, Information System Research,Vol.13 (1): 29-34.

Sidharta,Lani.1995.Pengantar Sistem Informasi Bisnis, P.T. ELEX Media Komputindo, Jakarta

Utami,Warih Andini, Febrilian Samopa.2015.Analisa kesuksesan sistem informasi akademik (siakad) di perguruan tinggi dengan menggunakan D \& M IS Success Model (Studi kasus:ITS Surabaya).Institut Teknologi Sepuluh Nopember Surabaya

Wahyudi, Riza, Endang Siti Astuti dan Riyadi.2015.Pengaruh Kualitas Sistem, Informasi dan Pelayanan Terhadap Kepuasan Mahasiswa.Jurnal Administrasi Bisnis (JAB) Vol.23 No.2 Juni 2015. 